\title{
Coins and Identity: From Mint to Paradise
}

\author{
Lucia Travaini
}

\section{Identity of the State: Words and Images on Coins}

The images and text imprinted with dies transformed disks of metal into coins and guaranteed them. The study of iconography on coins is therefore no less important than that of its other aspects, although each coinage should be studied together with the entire corpus of data and especially with reference where possible to its circulation. ${ }^{1}$ It may be difficult sometimes to ascertain how coin iconography was originally understood and received, but in most cases it is at least possible to know the idea behind the creation of different types, the choice of a model or of a language, as part of a crucial interaction of identity between the State and its coinage. We shall examine first some examples of the creative phase, before minting took place, and then examples of how a sense of identity between the coins and the people who used them can be documented, concluding with a very peculiar use of coins as proof of identity for security at the entrance of gates of fortresses at Parma and Reggio Emilia in 1409. ${ }^{2}$

1 St Isidore of Seville stated in his Etymologiae that "in coins three things are necessary: metal, images and weight; if any of these is lacking it is not a coin" (in numismate tria quaerentur: metallum, figura et pondus. Si ex his aliquid defuerit nomisma non eriit) (Isidore of Seville, Origenes, Vol. 16, 18.12). For discussion of method, see Elkins and Krmnicek, Art in the Round, and Kemmers and Myrberg, "Rethinking numismatics".

2 For many aspects related to coins and identity, see the papers presented at the symposium "Monnaies et identités" organized by Catherine Grandjean (University of Tours) in 2009 and published in Revue Numismatique 169 (2012), particularly those of Grandjean and of Marc Bompaire (both quoted below); see also the contributions in Solway, Medieval Coins and Seals; and especially Bedos-Rezak, "Medieval identity". On coins as identity of the state in Byzantium and medieval Europe, see the many contributions by Philip Grierson (e.g., The Coins of Medieval Europe and Catalogue of the Byzantine Coins) and, for portraits, Travaini, I capelli di Carlo il Calvo. On coins as signs of identity and memory for those who used them and in ritual contexts, see Travaini, "Saints and sinners"; Travaini, "Saints, sinners and ... a cow"; Travaini, "La moneta in viaggio", pp. 91-94; and Travaini, Il lato buono della monete. 


\section{Before the Mint: The Moment of Creation}

The role of coins as tokens of identity must be considered from their very origin, even before their production in the mint. I refer here not to the general theme of the "invention" of the first metallic coins, ${ }^{3}$ but to the circumstances which induced a state (whether an individual ruler or a city) to strike them, the moment when they were imagined or conceived in weight, fineness, and images. Instructions and models of the chosen images were then passed on to those in charge of the mint. Many documents can shed light on the bond between the State and its coins.

The oldest evidence of this comes from Sestus in Thrace in circa 120 B.C.; an inscription informs us not only that the city would profit from its bronze coins (presumably overvalued in relation to the silver coins) but also that "the striking of coins will make the city's character current". In this context the term character may well refer to the coin types, or the city's emblem; although the surviving coinage of Sestus bears a variety of types, the original intention may have referred to a diffusion of its signs of identity, such as the representation of Demeter, whose cult was strong in the city. ${ }^{4}$

Religious images indeed identified and protected the status of power. The coins of Athens carried on one side the profile head of the goddess Athena and on the other the owl, often associated with the goddess. According to three inscriptions dated respectively shortly after $385-384$ B.C., $369-368$ B.C., and $368-$ 367 B.C., some dies and anvils for striking gold coins were kept in the Parthenon, stressing the religious value of issuing coins and the sacrality of the mint. ${ }^{5}$

Terrestrial rulers did portray themselves with divine attributes on coins through the centuries: tetradrachms of Alexander the Great (336-323 B.C.) do not bear his personal portrait but show on one side the head of Heracles, as Alexander's identity, and Zeus on the other. Emperor Nero (A.D. 54-68) introduced his radiate portrait on some of his coins, when previously the only radiate image had been that of the god Sol. There were also religious dimensions to special issues. One may cite the Byzantine emperor Alexius III Megas of Trebizond (1349-1390) who, after a chrysobull dated 1374, inaugurated an

3 The origin of money is a topic of great relevance to historians, numismatists, and economists: see Grierson, The Origins of Money; Ingham, The Nature of Money beginning on p. 89; for the earliest coinage, see Seaford, Money and the Early Greek Mind beginning on p. 125.

4 Melville Jones, Testimonia Numaria, Vol. 2, p. 213 no. 377; Picard, "Iconographie et mémoire monétaires", p. 45.

5 For the inscriptions, see Melville Jones, Testimonia Numaria, Vol. 1, pp. 167-69, nos. 169-70 and ${ }_{174-75}$, and Melville Jones, Testimonia Numaria, Vol. 2, pp. 104-6. For the sacrality of mints, see Travaini, "Sacra moneta", and Grandjean, "Identité civique", pp. 12-13. 
annual grant of a thousand aspra defined as "my own God-guarded issue that are called 'Komnenata' ". 6

In many cases, the images of emperors and kings were carefully chosen to display the face of authority according to time and circumstances. Any coin bearing innovative or "daring" images must have certainly been ordered personally by the ruler and his closest councillors, and some images are recorded in written sources for their special impact. For example, the Byzantine emperor Isaac I Comnenus (1057-1059) was displayed on gold histamena in rather aggressive militaristic attire, brandishing his sword. His contemporaries thought it to be a sign of extreme pride on his part, as if he owed his throne to his military qualities and not to divine decree. ${ }^{7}$

Capitularies, edicts, or imperial or papal privileges imposed the types of new coins. In the Edict of Pîtres of 864 Charles the Bald ordered that the new denarii must bear on one side his name in a circular legend around his monogram, and on the other side the name of the city mint around a cross (ex una parte nomen nostrum habeatur in gyro et in medio nostrinominis monogramma, ex altera vero parte nomen civitatis et in medio crux habeatur). This type was introduced widely in the Carolingian Empire. ${ }^{8}$

In 1123 the Norman duke of Gaeta, Richard of Carinola, planned the issue of new copper coins supposed to bear his image (moneta nostrum imago), but the project was opposed fiercely. The city was ruled by consuls coordinated by the duke; they did not like Richard's attempt to show himself as a sovereign, so they made him promise that the coins "as we see them today ... would remain the same, fixed and unchanged for eternity" (predicta moneta follarum, sicut nunc esse videtur, ita taliter firma, stabilis et immobilis perseveret in sempiternum). ${ }^{9}$

In 1166 Emperor Frederick I Barbarossa (1152-119o) ordered the production of new denarii to be issued in the imperial city of Aachen: their types (forma) had to bear on one side the image and name of Saint Charlemagne and on

6 Hendy, Studies in the Byzantine Monetary Economy, p. 523: these were silver coins bearing on obverse and reverse (respectively) the images of St Eugenius and the emperor, both on horseback in similar positions. See below for more examples of this.

7 Grierson, Catalogue, pp. 759-6o, lists the contemporary sources.

8 Grierson and Blackburn, Medieval European Coinage (hereafter MEC) 1, p. 232; for the production of the new type, known as the Gratia $D(e i)$ Rex, and its mint attributions, see Grierson, "The 'Gratia Dei Rex' Coinage of Charles the Bald", pp. 52-64; Coupland, "Carolingian single finds and the economy of the early ninth century", and Sarah, "Charlemagne, Charles the Bald and the Karolus monogram coinage".

9 Travaini, La monetazione nell'Italia normanna, p. 337; Travaini, I capelli, pp. 187-88; and Grierson and Travaini, $M E C$ 14, p. 7 o. 
the other the image and name of the emperor. (It should be noted here that Frederick I had obtained the canonization of Charlemagne by antipope Pascal III the previous year. By this act, a saint emperor could be superimposed on and confused with the ruling one: power was transferred from Heaven to the physical throne. $\left.{ }^{10}\right)$ A few years after that, in Constantinople, the Byzantine emperor Alexius III Angelus Comnenus (1195-1203) represented himself on gold histamena together with the nimbate saint emperor Constantine the Great, each holding a patriarchal cross, probably with similar ends. ${ }^{11}$

Henry VI of Hohenstaufen (emperor 1191-1197) became king of Sicily on 25 December 1194 (he was married to King Roger II's daughter Constance). His Sicilian coins show a complete break from the Norman traditions, stressing above all his imperial sovereignty; an empire includes by definition a multitude of kingdoms or principalities, but the Kingdom of Sicily was extremely important and rich at this time and it was a major international coup to have it unified with the Roman Empire. By stressing his imperial image and titles, Henry's Sicilian coins demonstrate how carefully the imperial chancery had built his power on image control: copper coins were altogether abolished, Arabic legends were replaced by Latin ones on many coinages, and when they were kept, as on the gold Sicilian taris, they abandoned the Fatimid style of the Norman kings by stating his Roman imperial titles transliterated into Arabic from Latin: Harir Qaisar Awgust, Henry Caesar Augustus. ${ }^{12}$

Frederick II of Hohenstaufen became king of Sicily following the premature death of his father Henry VI in 1197, then emperor in 1220 until his death in 1250. His early coins in the Kingdom of Sicily, under the regency of his Norman mother, show a return to Norman traditions, including the use of the Arabic al mu'azzam (the magnificent) dynastic title of the Norman kings from the time of Roger II. His billon coins issued at Messina and Brindisi show how his titles were progressively modified in accordance with his evolving status: 1212 King of the Romans, 1220 emperor, 1225 King of Jerusalem. The most striking

10 These denarii were never produced. The text is: forma vero denariorum talis erit, quod in una parte erit imago sancti Karoli et eius superscriptio, ex altera parte nostra imago cum nostri nominis superscriptione ("the types of the denarii be on one side the image of Saint Charles and his name, and on the other side our image with our name"): Monumenta Germaniae Historica Vol. 10, Part 2 (hereafter MGH), p. 435, n. 503. Similar superimposed images of celestial and terrestrial rulers can be seen for Bishop-Duke Athanasius II of Naples (878-898), Pope Sergius III (904-911), Wenceslaus IV of Luxembourg, king of Bohemia (1378-1419), and Djuradi Branković, lord of Ragusa/Dubrovnik (c.1402-1427): Travaini, I capelli, pp. 174-75, 234, and 238 .

11 Callegher, "Da imperatore a santo militare".

12 Grierson and Travaini, MEC 14, pp. $15^{2}$ and 443; Travaini, I capelli, pp. 192-94. 
and imposing impact was reached with the gold augustalis issued in 1231: it bears on one side the imperial laureate bust with IMP ROM CAESAR AVG and on the other an eagle with spread wings and +FRIDERICVs; imperial on both sides, with its $20^{1 / 2}$ carats gold and weight of $5.31 \mathrm{~g}$, this coin was very new in the Sicilian as well as the international panorama, and was meant to reveal the imperial image and arouse devotion and fidelity to his luminous majesty. ${ }^{13}$ It was a successful coin and massively produced, and was the masterpiece of Frederick's conscious propaganda.

In the north of Italy Frederick II had to fight against the communes and the pope; towards the end of his life, after being excommunicated for the third time and having lost ground on various fronts, in December 1248 he granted the city of Tortona the privilege to issue new coins in his honour, bearing on one side his name and image, making clear the intention, already expressed for the augustalis, that frequent contact with his image would stir and always increase the devotion of his subjects. ${ }^{14}$

These documents and coins make us understand how conscious rulers could be of coinage as an expression of their identity. This began well before we find it explicitly expressed and recommended to rulers in the treaty De Regimine Principum (On the government of rulers) by St Thomas Aquinas (d. 1274), completed by Ptolemy of Lucca (d. 1327?). Ptolemy wrote a specific sentence on coins, calling them "the peculiar adornment of the king ... because on coins the image of the king as Caesar is represented ... and no other things can display the clarity of his memory like coins" (nummisma sive moneta propria ornamentum est regis ... quia in ea repraesentatur imago regis ut caesaris ... unde in nulla re tanta potest esse claritas memoriae ejus ... quantum nummisma). ${ }^{15}$

Many of the examples given above are related to coins well-documented in contemporary official texts; some of the latter have not survived, or may not have been struck as intended. But many coins, even in the absence of

\footnotetext{
13 Grierson and Travaini, MEC 14, pp. 157-70; Travaini, I capelli, pp. 194-97.

14 ... ut cudendi monetam in civitate Terdonem ad honorem nostri culminis, ut ipsa nova monetae forma nostri memoriam nominis et nostre maiestatis imaginem eis iugiter representet ... et ut frequens ipsius nove monetae inspectio eos in fide et devotione nostra magis ac magis corroboret et accendat ("to issue coins in our city of Tortona in the honour of our majesty, so that the images of the new coins represent the memory of our name and the image of our majesty, and in order that the frequent observation of these coins may invigorate and awaken more and more their faith and devotion for us"): Huillard-Bréholles, Historia diplomatica, Vol. 6, Part 2, pp. 669-70; Travaini, I capelli, p. 208. (These coins are not known and may never have been minted.)

15 Thomas Aquinas, Tractatus de regimine principum (de rege et regno), ch. 13, p. 367 ss.; Ptolemy of Lucca, On the Government of Rulers, Vol. 1, Section 13. For the attribution to Ptolemy of Lucca, see Wittreck, Geld als Instrument der Gerechtigkeit, pp. 705-8.
} 
documentary evidence, can speak for themselves - and besides, they are solid written evidence as well.

We can detect the moment in which some states or rulers acquired a sense of full awareness of their status and independence. Theoderic, king of the Ostrogoths (493-526), did not sign his gold solidi and tremisses, which occasionally bear his monogram; however, we have a unique specimen of a gold medallion which shows his moustached bust holding a globe surmounted by Victory in its left hand and making a gesture of adlocutio with its right. No barbarian king was supposed to display his image on gold coins; in fact, early post-Roman barbarian gold coins were imitations in the names of late imperial or early Byzantine rulers. Theoderic's medallion, with his name as a victorious prince, was a strong statement of independence and power: however, the denomination was of very high value (three solidi) and was not struck for circulation, but to be offered to those close to the king. ${ }^{16}$

The Lombard kings continued producing gold tremisses in the name of Byzantine emperors as had their Ostrogothic predecessors. Only King Cunincpert in 692 introduced a new coin type with his name clearly indicated, and on the other side the image of St Michael Archangel, the national saint of the Lombards and the first saint ever represented on coins. ${ }^{17}$ Men in the Lombard nation wore long beards but these were not depicted on the contemporary tremisses, which imitated the profile of Roman tradition. Only when King Aistulf (749-756) conquered Ravenna from the Byzantines in $75^{1}$ did he issue coins showing himself in his more authentic appearance: the bearded facing bust on these coins, which has sometimes been considered a copy of an image of Emperor Phocas, should be viewed as an original "portrait" of the Lombard identity. ${ }^{18}$

If the rulers of the Kingdom of Italy were more cautious and respectful of the imperial prerogatives on gold coins, some earlier signs of independence from Byzantium were shown by other rulers. The Merovingian Theodebert I of Metz (534-548) signed his gold solidi and aroused violent comments in Constantinople, made explicit by Procopius: "it is not considered right ... for any ... sovereign in the whole barbarian world to imprint his own likeness on a gold stater". ${ }^{19}$

16 Much has been written about this medallion, and its date is debated (Rome A.D. 50o?): see Grierson and Blackburn, $M E C$ 1, p. 35; and Travaini, I capelli, p. 146.

17 Grierson and Blackburn, $M E C$ 1, p. 64; Arslan, "San Michele"; and Travaini, I capelli, p. 154.

18 Grierson and Blackburn, $M E C$ 1, p. 65; and Travaini, I capelli, p. 155.

19 Procopius, History of the Wars, Vol 3, p. 33 (quoted from Spufford, Money and Its Use in Medieval Europe, p. 14); Grierson and Blackburn, $M E C$ 1, p. 116-17; and Travaini, I capelli, p. 149 . 
The Visigoths in the Iberian peninsula gave special characters to the style of their gold, and by $c .580$ King Leovigild (c.569-586) was already signing his gold coins with his name, as his successors did until $714 .^{20}$

The early Scandinavian coins minted in Denmark were anonymous and imitative of Anglo-Saxon types until proper regal coinages were introduced, still following the same model, but identified and self conscious in the name of the kings. This occurred under, respectively, Sven Forkbeard of Denmark (9861014), Olaf Tryggvasson of Norway (995-1000) and Olof Skötkonung of Sweden (994-1022). ${ }^{21}$ Occurrences of this pattern are so numerous as to be almost the rule: identity made itself manifest when rulers acquired power and local control and could make their coin types independent from previous models. Some good examples are shown by European imitations of the gold florin of Florence. The early florins of Hungary were issued from 1325 by King Charles Robert of Anjou (1308-1342); they bore the images of St John the Baptist on one side and the lily on the other, like the original model, but replaced the legend FLORENTIA with the king's personal name. This type was continued by King Louis I (1342-1382), who introduced a national type in 1353, removing the lily and replacing it with the arms of Hungary and Anjou. ${ }^{22}$

We can imagine the Catalan count Ermengol v of Urgell (1092-1102) being shown an ancient coin found locally: an Iberian silver denarius or copper ass of Bolskan of the 2nd century B.C. showing on one side a horse-mounted lancer (Figure 13.1). The count must have recognized his own ideal image on the old coin, and must have ordered the mint to strike billon deniers showing the same image perfectly copied, including the Iberian legend in the exergue, with his own name ERMENGAVDVS inscribed on the other side around a cross (Figure 13.2). This coin in itself, with its mix of current and archaic text and images, can tell us a lot about the sense of identity, pride, and culture of the time. ${ }^{23}$

The name of Sancerre, in the French county of Berry, took its origin from Saint Satyrus ("Serre"), whose relics were brought there in the 7 th century; however, in the early 12th century, the name Sacrum Cesaris was favoured, based on a made-up classical past presuming a foundation by Julius Caesar. This prefabricated past was promptly struck on its coins, with the (medieval

$20 \quad$ Pliego Vàzquez, La moneda visigoda, Vol. 1, pp. 81-83: the signed type follows the introduction of the cross-on-steps type by Tiberius II Constantine (578-582). Travaini, I capelli, p. 159 .

21 For the three coinages, see Malmer, The Anglo-Scandinavian Coinage, p. 53; Malmer, Den svenska mynthistorien, pp. 22-28; Gullbekk, "The church and money in Norway" beginning on p. 223.

22 Grierson, Coins, p. 170.

23 Crusafont, Balaguer, and Grierson, MEC 6, p. 92. 

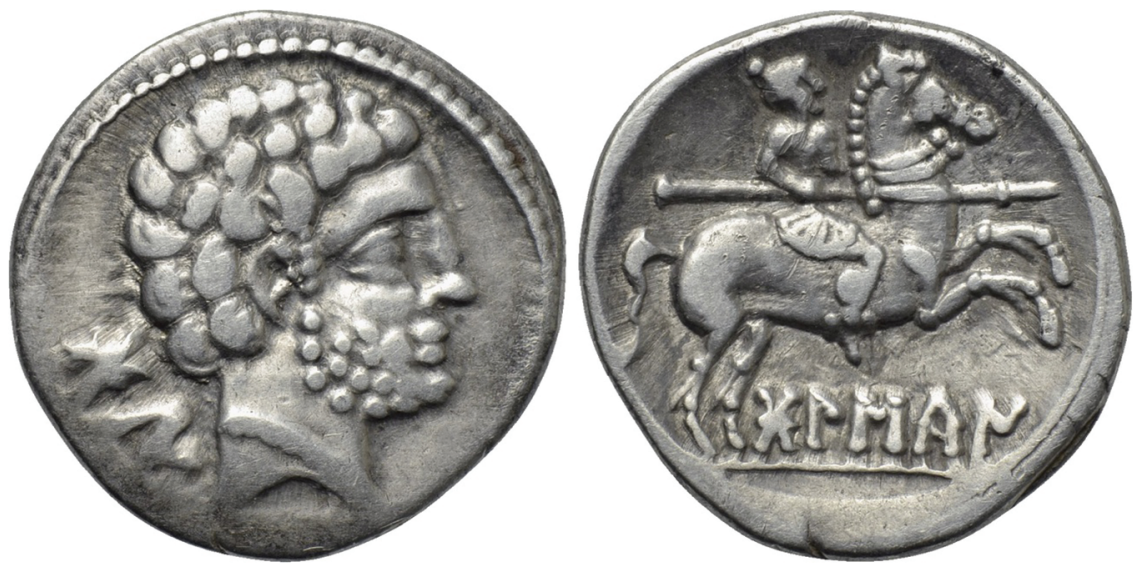

FIGURE 13.1 Silver denarius of Bolskan 4.11G, diameter 18mm.

SOURCE: NUMISMATIK NAUMANN GMBH, VIENNA, AUCTION 50, 5 FEBRUARY 2017, LOT 53.
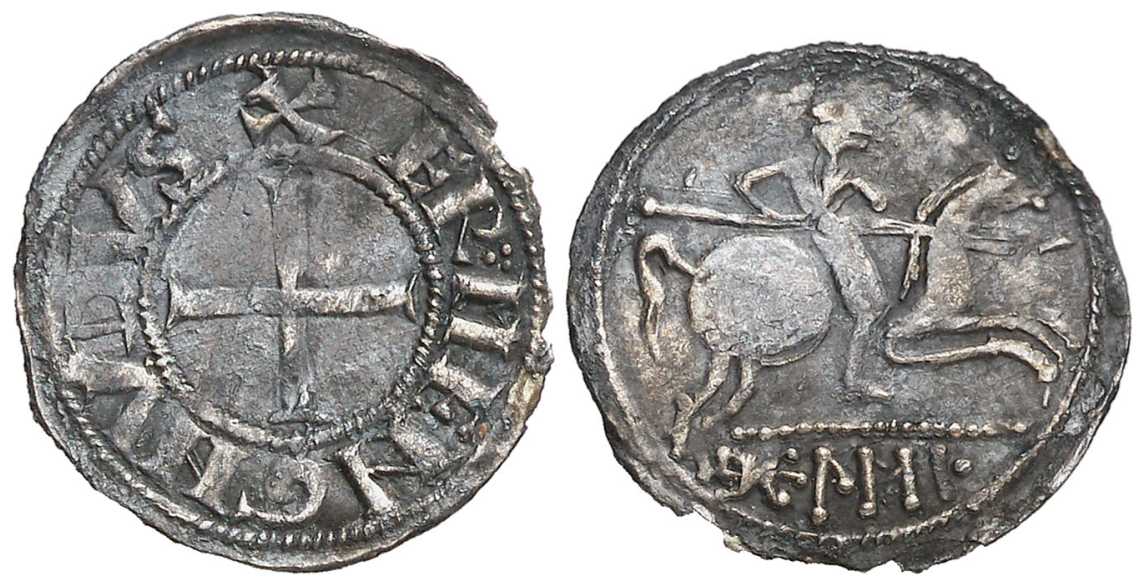

FIGURE 13.2 Count Ermengol v of Urgell (1092-1102), billon denier 0.91G, diameter 18M. SOURCE: PRIVATE COLLECTION, AUREO \& CALICÒ, SUBASTA PUBLICA, BARCELONA 27 OCTOBER 2011, LOT 76.

and bearded!) head and name of IVLIVS CESAR on one side and a cross and the name of the local count on the other (Figure 13.3). ${ }^{24}$ The iconography of medieval European coins should be explored in more depth than it has been so far.

24 Travaini, I capelli, pp. 33 and 45. 

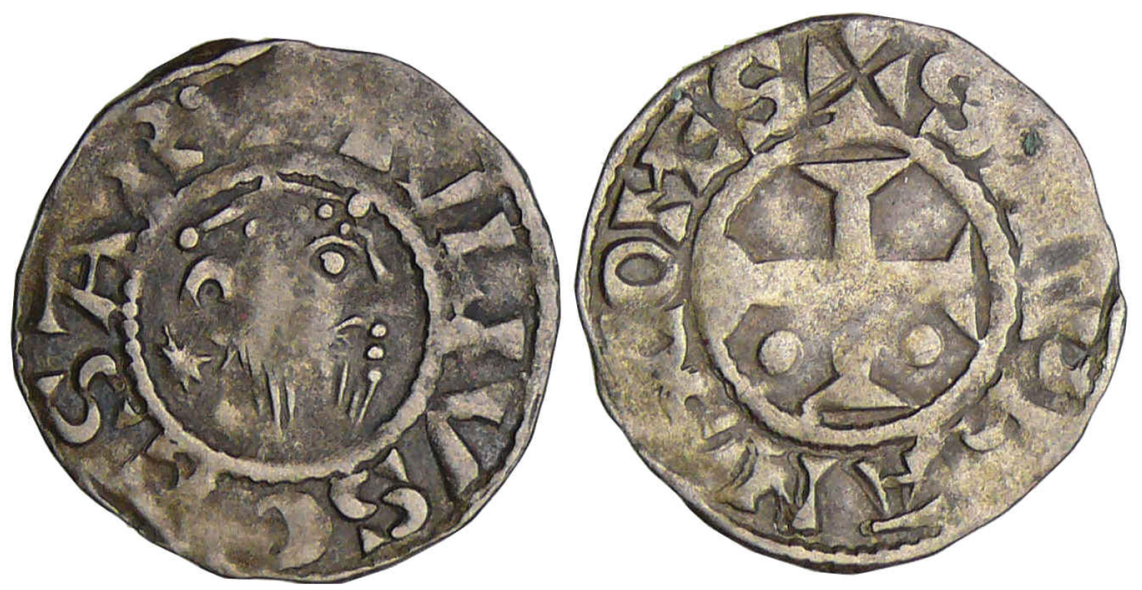

FIGURE 13.3 Sancerre, billon denier of Count Steven II of Champagne and I of Sancerre (1152-1191) O.99 G, 19 mm. SOURCE: MONNAIES D'ANTAN, AUCTION 16, 22 NOVEMBER 2014, NO. 612).

\section{Mints: The Moment of Production}

Mints were at the heart of the State, and were kept close to the centre of power. We can see this evidenced by the central location of mints in cities, and the sentiment of pride disclosed by a number of documents. The deathbed oration of the Venetian doge Tomaso Mocenigo (1414-1423) is a good example: "You have seen our mint strike every year one million two hundred thousand gold ducats and in silver coins, among grossetti, mezzanini and soldini, 800,000 [ducats worth] a year". Although the figures may not all be consistent, the mint was in the heart of the dying doge. ${ }^{25}$

The mints could strike prestigious images but were also a source of income, exploited for fiscal purposes. Frederick II used and abused the mints of Brindisi and Messina for the production of progressively debased billon denarii, especially from the late 1230 s until his death in 125 . In 1238 he was besieging the city of Brescia and needed cash urgently; in a letter to the Kingdom of Sicily he

25 Stahl, Zecca, pp. 379-82. Some 13th- and 14th-century Italian cities documented their pride in their mints by striking coins out of spite; for example, in 1299 a small Venetian expedition disembarked on the quay of the port of Genoa and there raised the banner of St Mark and struck Venetian ducats, "leaving the Genoese shamed and disgraced" (cum magna infamia, damnis et dedecore Januensium): Grierson, "'Coniazioni per dispetto' nell'Italia medievale", p. 345 . 
ordered his vicars to provide a new issue of these debased coins and said that he was "enclosing models of the new images to be struck" (formam ... interclusam... sub quibus autem ymaginibus hec nova pecunia cudi debeat) ${ }^{26}$

\section{Competition}

The ability to express identity through coins created opportunities for competition between states, especially in the case of imitations. States wanted to have their coins accepted in foreign markets, which was supposed to guarantee economic rewards by avoiding having to exchange gold or silver for somebody else's coins, but it was also a matter of prestige. Some examples of competition can be observed among the Italian cities. The gold florin of Florence was first issued in 1252: its types are the fleur-de-lis and the standing image of John the Baptist, patron saint of the city, with pure fineness of 24 carats and weight of $3.53 \mathrm{~g}$. The gold ducat of Venice was first ordered in 1284 and struck beginning in 1285. The mint order stated that it should be as good as the florin or even better in gold (tam bona et fina per aurum vel melior ut est florenus) but the types were independent, ${ }^{27}$ showing Christ in a mandorla on one side, and on the other St Mark offering the staff to the kneeling doge.

By 1300 the florin was the most important gold coin in circulation in Europe and to begin with also in the Levant, where the ducat replaced it in the first half of the 14th century. Writing in the 1320s, Florentine merchant and chronicler Giovanni Villani (1276-1348) told a story of how the sultan of Tunis had admired his gold florins and granted the Florentines the same trade privileges as the envious Pisans. These are his words:

The said new florins having begun to circulate through the world, they were carried to Tunis in Barbary; and being brought before the king of Tunis, which was a worthy and wise lord, they pleased him much, and he caused them to be tried; and finding them to be of fine gold, he much commended them, and having caused his interpreters to interpret the imprint and legend on the florin, he found that it said: S. John the Baptist, and on the side of the lily, Florence. Perceiving it to be Christian money, he sent to the Pisan merchants who were then free of the city and were

26 Grierson and Travaini, $M E C$ 14, p. 182; Acta Imperii, vol. 1, p. 637. On the iconography and diffusion of these denarii, see Travaini, I capelli, p. 199.

27 Stahl, Zecca, pp. 28-33; and Grierson, "The fineness of the Venetian ducat and its imitations", p. 95 . 
much with the king (and even the Florentines traded in Tunis through the Pisans), and asked them what manner of city among Christians was this Florence which made the said florins. The Pisans answered spitefully through envy, saying: "They are our inland Arabs": which is to say, "our mountain rustics". Then answered the king wisely: "It does not seem to me the money of Arabs. O you Pisans, what manner of golden money is yours?" Then were they confused, and knew not how to answer. He asked if there were among them any one from Florence, and there was found there a merchant from Oltrarno, by name Pera Balducci, discreet and wise. The king asked him of the state and condition of Florence, whom the Pisans called their Arabs; the which answered wisely, showing the power and magnificence of Florence, and how Pisa in comparison was neither in power nor in inhabitants the half of Florence, and that they had no golden money, and that the florin was the fruit of many victories gained by the Florentines over them. For the which cause the Pisans were shamed, and the king, by reason of the florin and by the words of our wise fellow-citizen, made the Florentines free of the city, and allowed them a place of habitation and a church in Tunis, and he gave them the same privileges as the Pisans. ${ }^{28}$

Cominciati i detti nuovi fiorini a spargersi per lo mondo, ne furono portati a Tunisi in Barberia; e recati dinanzi al re di Tunisi, ch'era valente e savio signore, sì gli piacque molto, e fecene fare saggio, e trovata di fine oro, molto la commendò, e fatta interpetrare a' suoi interpetri la 'mpronta e scritta del fiorino, trovò dicea: «Santo Giovanni Batista»; e dal lato del giglio: "Fiorenzia". Veggendo era moneta di Cristiani, mandò per gli mercatanti pisani che allora erano franchi e molto innanzi al re (e eziandio i Fiorentini si spacciavano in Tunisi per Pisani), e domandogli che città era tra' Cristiani quella Florenza che faceva i detti fiorini. Rispuosono i Pisani dispettosamente e per invidia, dicendo: "Sono nostri Arabi fra terra", che tanto viene a dire come nostri montanari. Rispuose saviamente il re: "Non mi pare moneta d'Arabi; o voi Pisani, quale moneta d'oro è la vostra?". Allora furono confusi e non seppono rispondere. Domandò se tra-lloro era alcuno di Florenza; trovovisi uno mercatante d'Oltrarno ch'avea nome Pera Balducci, discreto e savio. Lo re lo domandò dello stato e essere di Firenze, cui i Pisani faceano loro Arabi; lo quale saviamente rispuose, mostrando la potenzia e la magnificenzia di Fiorenza, e come Pisa a comparazione non era di podere né di gente la metà di Firenze, 
e che non aveano moneta d'oro, e che il fiorino era guadagnato per gli Fiorentini sopra loro per molte vittorie. Per la qual cagione i detti Pisani furono vergognati, e lo re per cagione del fiorino, e per le parole del nostro savio cittadino, fece franchi i Fiorentini, e che avessono per loro fondaco d'abitazione e chiesa in Tunisi, e privilegiogli come i Pisani.

In 1422 Florence tried to impose the gold florin over the ducat of Venice in the eastern markets. In their first journey that year to Alexandria, their newly built ships took not only goods (4,00o florins worth), but also 56,0oo gold ducats of Venice, the only accepted gold currency there, for buying spices; at the same time the ambassadors there were able to show the sultan their new fiorini larghi, also named di ghalea ("of the ship"), issued in 1422 with the usual iconography but with a slight weight increase and larger diameter to compete with the ducat. ${ }^{29} \mathrm{~A}$ much earlier case of monetary competition is documented between Rome and Persepolis: was this at least in part a literary topos? $?^{30}$

\section{Imitations: Using and Abusing Others' Identities}

The iconography of coins was not a protected brand and imitation of successful coins was frequent from Antiquity onwards. Legal imitations revealed the identity of the issuing authority with its name or symbols, and although these coins' weight and fineness may have been inferior to those of the original, they were generally tolerated, or at least nothing could really be done against them. In reality, it was a sensitive topic. Imitations entered into competition with the original coins. ${ }^{31}$ Special sensitivity was occasionally documented and these cases offer interesting insight into the sense of "identity". Let us consider Florence and Venice in relation to other State authorities.

In 1350 the mint of Rome issued gold ducats in the name of the Roman Senate but imitating those of Venice. Why the Venetian model and not the

29 The ceremony of the launching of the ships is recorded in detail, along with the contents of their cargo: Sapori, "I primi viaggi di Levante e di Ponente delle galee fiorentine", pp. 910; and Tripodi, "Viaggi di ambasciatori tra Firenze e il Cairo nel xv secolo", p. 416.

30 Alram, "Monnayage, prestige et identité".

31 The major concern in case of imitations was the risk of the original coins being hoarded or melted, favouring the circulation of lesser-quality ones according to Gresham's law. Illegal forgeries copied the types of the original coin as closely as possible, and were made by covering a base flan with a gold or silver surface. Counterfeiting was considered a treasonous crime, because the fakes diminished the authority of the power behind the 
Florentine? Both gold coins were common in the Papal State. While it is possible that the Florentine merchants in charge of the mint of Rome simply did not like the florin to be imitated (as was actually documented later), the Venice type offered a more suitable iconographic scheme. The image of St Mark offering the staff to the doge could be easily adapted to show St Peter offering the staff to the kneeling senator of Rome, suggesting "the superiority of the spiritual power without showing the senator accepting the symbol of office directly from the pope". ${ }^{32}$ We know of no protest from Venice against the Senate of Rome; instead, in 1355 Venice sent a letter accusing the Genoese lord Francesco Gattilusio of producing forgeries of the ducat in his mint of Metelino in the island of Lesbos. (They defined the coins as apparentia consimilem, immo verius sub ducati Venetiarum communis proprio stigmata [so similar in appearance, with the symbols typical of the ducat of the commune of Venice].) The Genoese authorities ordered Francesco to stop making his forgeries ... but in fact the accusations were false: a recent discovery found a specimen of the ducat of Metelino, of very good fineness, with Francesco's name clearly stated and with his image kneeling in military attire. In July 1355 he had been made lord of the island by the Byzantine emperor John v Palaeologus and therefore had minting rights; he may have produced some anonymous imitations before, but these new ducats were an independent statement of conscious propaganda. ${ }^{33}$

The first imitations of the florin were produced by Pope John XxII (13161334) in Pont-de-Sorgues (Comtat Venaissin). He did this in agreement with the commune of Florence, following the original standard of weight and fineness and placing crossed keys and COMES VENESI or SANCT PETRV in the legend around the lily so that the coins could thereby be identified and attributed correctly. As far as we know, Florence did not protest formally and actually sent the necessary weight-samples needed to produce good gold florins. Later

legitimate coins. I will not deal with counterfeiting here but one may consider, for example, the Roman law of A.D. 381 which added to the usual list of capital offences that of "the person practiced in sacrilege who reproduces the sacred countenance and lays impious hands upon the divine features by engraving them on sacred objects." (For this and more examples, see Grierson, "The Roman law of counterfeiting”, p. 250.)

32 Day, "Antiquity, Rome and Florence", p. 257. Rome had previously issued briefly a gold coin imitating the florin (c.1339-1340) (see ibid., pp. 248-49). The earliest gold romanini, dated c.1270, had autonomous types bearing the crowned personification of Rome seated on a throne and holding a globe and palm branch, with the legend Roma Caput Mundi (Travaini, "Per Philip Grierson").

Oberlaender-Târnoveanu, "Immo verius sub ducati Venetiarum communis proprio stigmate". 
Giovanni Villani, full of resentment, accused the pope of "disguising" the florin. ${ }^{34}$ He reported that in December 1324 Pope John had excommunicated anyone who "counterfeited" the florin of Florence and "corrected others, when he should have corrected himself". ${ }^{35}$ Obviously, Villani here represents civic pride, and does not take into account the legal aspects of imitations as opposed to mere forgeries.

In the course of the 14th century many mints in Europe were administered by Italian merchants, including Florentines, and a number of these issued imitations of the florin. However, in 1368 the Florentine mintmaster in Rome wanted to protect his city's coins. That year Pope Urban v returned to Rome from Avignon and introduced monetary reforms; ${ }^{36}$ he wanted to produce imitations

34 "Papa Giovanni fece fare in Vignone una nuova moneta d'oro fatta del peso e lega e conio del fiorino d'oro di Firenze sanza altra intransegna, se non che da.lato del giglio diceano le lettere il nome del papa Giovanni; per la qual cosa gli fue messa grande riprensione, a fare dissimulare sì fatta moneta come il fiorino di Firenze" ("Pope John had a new gold coin made in Avignon, of the same weight, fineness, and stamp of the gold florin of Florence, without any other marking except his name written on the side of the lily; and for this reason he was highly criticized for such a deception") (Villani, Nuova Cronica, Vol. 8, p. 171). The weight standards arrived from Florence on 15 September 1322 and the production started soon after: Bompaire, "La monnaie de Pont-de-Sorgues dans la première moitié du XIVe siècle", p. 151; and Day, "Antiquity, Rome and Florence", pp. 246-47. Later, more mints imitated the florin but not always at the original fineness.

35 "Nel detto anno e mese di dicembre papa Giovanni fece grandi processi e scomunica contra chiunque facesse battere o battesse fiorini d'oro contrafatti e falsi a la forma di que' di Firenze, però che per molti signori erano fatti falsificare, com'era il marchese di Monferrato e Spinoli di Genova. Ma il papa per sue scomuniche corresse altrui, ma in questa parte non corresse sé medesimo, ché fece fare i fiorini a la lega e conio di quegli di Firenze, e non v'avea altra differenza, se non che dal lato de la 'mpronta di santo Giovanni diceano le lettere: «papa Giovanni», e per intrasegna, di costa al santo Giovanni una mitra papale, e dal lato del giglio diceano le lettere: 'sancto Petro et Pauli' " "In the month of December of that year Pope John held trials and excommunicated any one found striking counterfeit florins similar to those of Florence, as in fact many lords had produced, such as the Marquis of Monferrato or the Spinola of Genoa. In doing so the pope corrected others, when he should have corrected himself, because he ordered florins minted similar to those of Florence, the only difference being the letters papa Giovanni and a papal mitre on the side with saint John, and the letters sancto Petro et Pauli on the side with the lily") (Villani, Nuova Cronica, Vol. 8, p. 278). I am grateful to Katherine L. Jansen for revising my translations in notes 34 and 35. On the use of florin imitations in Europe, see Spufford, Money and Its Use, pp. 319-21, and Day, "Antiquity, Rome and Florence", p. 248. A hoard of 210 gold ducats of Venice and florins of Florence found in Montella (Avellino) and buried c.1354 contained also 59 florin imitations from many European mints (Travaini and Broggini, Il Tesoro di Montella).

36 He introduced the new bolognino romano, and grossi of the same types as those of Avignon: Muntoni, La monete dei Papi e degli Stati pontifici, vol. 1, p. 30; and Martinori, Annali della Zecca di Roma, beginning on p. 5 . 
of the gold florin, but mintmaster Amario di Pietro de' Gianfigliazzi refused "on the grounds that the Florentine statutes prohibited any Florentine from striking false florins under penalty of death". ${ }^{37}$ The pope declared that the papal florins would not be false because they would be not only as fine and good as the originals, but easily distinguished by the descriptio (obverse legend) and intersigna (privy mark). He petitioned the government in Florence on the matter, but the project failed and the mint continued to produce ducats of Venetian type.

\section{Power and Self-Confidence: Market and Legal Rules}

Even a dramatic change of government did not necessarily mean a change in coin iconography. Strong statements were normally first made on other media, such as seals; the new power had to enforce local control before changing the face of coins. The Normans conquered Sicily and took Palermo from the Arabs in 1072, but continued to strike quarter dinars there in Arabic with verses of the Koran and with the new ruler's names transliterated into Arabic. ${ }^{38}$ The Crusaders in the Holy Land continued the production of dinars in Arabic, and although they developed individual patterns, they never included their authority or names. ${ }^{39}$ The Latin emperors of Constantinople after 1204 also never issued coins in their own names, but only imitated Byzantine ones. ${ }^{40}$

Personal pride had on one hand to comply with the rules of the monetary market and on the other to match the legal status of authority. Many Renaissance lords in Italy had portrait medals produced by artists such as Pisanello or Matteo de' Pasti, but only a few of them would display the same portrait on their coins. King Ferdinand of Naples was the first to do so in $145^{-1459 \text {, }}$ and Duke Francesco Sforza in Milan followed in 1462. Borso d'Este had to wait to strike portrait coins in Ferrara until he was made duke by the pope in 1471; before then he was the Imperial Duke of Modena and Reggio, but only the Marquis of Ferrara and could not strike portrait coins of "ducal" aspect in that city. ${ }^{41}$

37 Day, “Antiquity, Rome and Florence", p. 256.

38 Travaini, La monetazione nell'Italia normanna, pp. 109-11.

39 They introduced Christian legends, still in Arabic, only after excommunication in 1250: Metcalf, Coinage of the Crusades and the Latin East in the Ashmolean Museum Oxford, pp. $43^{-} 5^{1}$ and $15^{-}-51$. For this and the Norman coinage, see Travaini, "Imitations and adaptations of Arabic coins in southern Italy, Sicily and the Holy Land".

$40 \quad$ Metcalf, Coinage, pp. 228-35.

41 Travaini, I capelli, pp. 264-71. 


\section{Identity of the User: Reading and Misreading Iconography}

Coins did bear the images of the issuing authority and, once in circulation, became a means of identity for those who used them. The same happens even today, when a country can be identified by a flag, a coin, and a football team. Literary evidence of coin images and coins as signs of identity is rare, but some medieval texts and coin-find contexts shed important light on this point.

Pilgrims from all over Europe carried their own current coins to Rome and other shrines. Everyday billon coins of low value normally had a very local circulation and were not accepted at foreign markets, while silver and gold coins could be exchanged for local coins through moneychangers on the way. In spite of this, low-value coins from different countries have been found in ritual contexts. After all, for a pilgrim, a small coin was a cheap and durable object that bore the images of his country and transformed an anonymous offer into a personal one through his or her intentions. ${ }^{42}$

An example of this comes from the excavations of the years 1940-1949 under the altar (Confessione) of St Peter's in the Vatican, near the tomb of the saint. A total of around 1,900 coins were found: 812 ancient Roman, 628 Italian, and 460 foreign coins dating from the 8 th to the $15^{\text {th }}$ centuries. The foreign ones were from mints in today's France, Germany, Switzerland, Low Countries, Spain, England, Ireland, Scandinavia, the Czech Republic, Latvia, Hungary, and Croatia. ${ }^{43}$ At least some of them must have been intentionally brought by pilgrims with the intention of offering a personal token of identity and memory in the form of coins "of their own country". Pilgrims travelled at great risk to reach a shrine and to pray there, asking for a special grace or an indulgence for themselves and their families. The memory of this spiritual and physical experience that brought them closer to God would always remain with them. It would seem quite reasonable to imagine that at the end of their long journey

42 In economics, a payment in coin is defined as "anonymous", unlike a payment through a bill of exchange which was signed. In the case of the ritual offering of a coin specifically selected to identify the pilgrim's provenance, the payment became somehow "invisibly signed": the coin created an invisible tie between the pilgrim and the saint. I thought of this "invisible tie" after watching tourists throwing coins in the Trevi Fountain with the wish to come back to Rome, and I first suggested a comparison with medieval offerings in Travaini, "Saints and sinners", pp. 172-73 (see also Travaini, "Le monete a Fontana di Trevi"). This view is now taken also by Gullbekk, "The church and money in Norway", beginning on p. 237.

43 Data taken from Serafini, "Le monete"; see also Arslan and Alteri, Le monete. Among these coins is one gold tremissis of Charles the Great: see Arslan, "Il dono di re Carlo all'apostolo Pietro". 
they wanted to touch the shrine of the saint and make that physical contact last by offering something of themselves. ${ }^{44}$ Low-value coins proved to be very useful for this purpose, ideal tokens of identity and personal memory to leave behind, attached to the shrine, to a saint's body or icon. ${ }^{45}$ The coins thus offered were usually of the type available to all, good for their moral value and for personal memory during a connected prayer (plea) or ex-voto (gratitude). ${ }^{46}$ The 1940 s find was a perfect confirmation of a statement made by Cardinal Jacopo Stefaneschi on the amount of money offered at the two altars of St Peter's and St Paul's in Rome in the 1300 jubilee:

Those altars, the most visited in the world, ... in this Jubilee year gave us, the one of the Prince [i.e., St Peter] thirty thousand florins, and the one of the Doctor [i.e., St Paul] about twenty one thousand, not made of large donations of gold or silver, but simply in small change of each country.

Quae celeberrima toto terrarum orbe altaria, singulis iamdudum annis, ex peregrinantium oblatis Apostolorum Principis Florinorum auri ... afferebant, milia triginta Principis circiter unum et viginti milia Doctoris hoc centesimo repulere, non ex magnis auri vel argenti donis, sed ex usualis monete provintie cuiusque minutis. ${ }^{47}$

For the period between 1382 and 1446 we have another important source on coins as identity in the Libro del pellegrino of the Siena State Archives. Pilgrims from all Europe on their way to Rome stopped at Siena, and deposited some of their money into the safe hands of the Ospedale di Santa Maria della Scala, opposite the Duomo, with the intention of withdrawing it on their way back home. These deposits are recorded carefully, together with the name and description of each pilgrim and his or her provenance: gold and silver coins were identified and described precisely, but coins of small value were simply recorded as "coins of his/her country" (monete di suo paese), the same sort of coins often offered by pilgrims at shrines. ${ }^{48}$

44 Offerings from antiquity included anatomical votives in the shape of parts of the body for which healing was requested.

45 Travaini, "Saints and sinners", pp. 172-74; Travaini, "Saints, sinners and ... a cow", pp. 215-16.

46 As note 45; Travaini, Il lato buono delle monete, beginning on p. 19; and Travaini, "La moneta in viaggio", pp. 91-94.

47 Frugoni, "Il giubileo di Bonifacio VIII", p. 123; Travaini, "Saints and sinners", p. 174; Travaini, "Saints, sinners and .... cow", p. 217. Stefaneschi had a relevant position in the Papal Curia and his words can be trusted.

48 Travaini, "La moneta in viaggio", pp. 91-94. Relevant evidence for this is related to Assisi and Rimini in the late 14th century, including the 1400 jubilee: Pigozzo, "I denari dei pellegrini", pp. 743-53. 
Pilgrims could be very determined in their desire to leave a trace of themselves at the shrine by inserting coins in statues or reliquaries. ${ }^{49}$ When the tomb of St Catervius in the Duomo of Tolentino was surveyed in 1750 many such coins were found, as well as belts and rosaries representing personal tokens. The tomb was in a Roman sarcophagus with a heavy lid sealed with plaster, but devout people "entered" the sacred space by breaking it open to insert their offering so that it could touch the sacred body. ${ }^{50}$

As symbols of richness and devil's tools, coins could be dangerous to the soul, but they could also aid in transactions between man and God via almsgiving, offerings, and the like. ${ }^{51}$ No doubt there were greedy priests requesting a penny from pilgrims as an offering to the church; but I am also sure that in most cases the coin was offered with devotion, as a physical touch or a personal contact to the saint: the offering was a sacred act, a gift to God, with a special intention of gratitude or plea. ${ }^{52}$

Once more mints became active in Europe and the volume and variety of coins in circulation had increased in the late Middle Ages, the link between

49 A Swedish bracteate of Magnus Eriksson (1319-1363) was found hidden in the hands of the statue of Saint Olaf in the Church of Lunner in Oppland: Skaare, "Universitets Myntkabinett". The bust reliquary of St James the Minor in Santiago de Compostela was made in 1332 and until 1388 was positioned so that devout pilgrims could touch it; during restorations, silver coins were found inserted in it from Castile, León, Navarre, England, and the Low Countries, as well as a bracteate of Schleswig, which were interpreted as pilgrims' offerings (Suárez Otero, "Arqueologia y peregrinación"; and Travaini, "Valori e disvalori simbolici delle monete", p. 35).

$5^{\circ}$ We must distinguish between coins offered over a long period of time at shrines or accessible saints' graves, and coins offered at the moment of an official survey by those responsible: the intention of the two groups was different. For the tomb in Tolentino, see Alteri, "Le monete dal sarcofago di Catervio" and Travaini, "Saints and sinners", p. 172.

$5^{1}$ For this topic, and the medieval exempla, see Bremond, Le Goff, and Schmitt, L' "Exemplum"; Thompson, Motif-Index of Folk Literature; and Travaini, "Saints and sinners", pp. 176-77. Also, the Charon's obol of classical tradition was a low-value coin, a symbol that death makes rich and poor equal. This perhaps explains why coins in Christian graves from the 12th century onwards were more commonly low-value coins: these were affordable to all. The use of placing a coin in the mouth in medieval graves is limited generally to former Byzantine territories; for evidence from southeastern Europe, see the bibliography in Travaini, "Saints, sinners and ...a cow", p. 214 n. 15, including also the exceptional evidence in the Salento with 14th-century graves belonging to communities of Albanian origin (Arthur, "Le monete").

52 The coins we find today in the excavation of a shrine may all be similar; however, some of them may have been charged with the ideal traces of the pilgrim's special devotion and intention, while others may have been offered by pilgrims just because they had to. An English Protestant traveller to Loreto in 1594, disguised as a Catholic, challenged the tradition of coin-offering at the altar, mocking the idolatry of saints. Instead of offering 
one's coin and country and oneself became stronger and easier, and also the number of offerings increased.

The conflicting aspects of coins - bad and good according to circumstances and points of view - are somehow magnified when studying Saint Francis of Assisi. Saint Francis wanted to protect his friars from the "contamination" of money, and in the Regola bollata of 1223 he prohibited the friars from accepting denarios aut pecuniam, i.e., coins and money in all forms. Still, coins were found in the saint's grave in the survey of 1818 . The explanation given by the experts in charge of the survey was that coins had been inserted by those who buried the saint ad indicandum tempus, i.e., as a chronological token or memory of their own time. I believe this was correct. ${ }^{53}$ Saints' graves were the object of surveys and relocations from one part of a church to another. Also, saints' bodies could be dismembered in order to offer parts to new churches, or their graves inspected either to make sure that no parts had been taken or that it was really the original and not that of an impostor. This is, in my opinion, the reason why coins were deposited in saints' graves, including that of St Francis of Assisi, who had forbidden the friars to accept them even as alms.

The grave of St Geminiano in Modena's cathedral is particularly interesting. The saint was a bishop of Modena who died in 397. A basilica ad corpus was built on his grave, which was surveyed three times: in 1109, 1184, and 1955, when 72 coins and two silver crosses found with the bones could be attributed to the previous surveys. ${ }^{54}$ In 1109 the sarcophagus had to be moved to a new location in the newly built church we see today. A survey of the body was undertaken in the presence of Countess Matilda of Canossa and the bishop: 19 denarii can be dated to this time, and the two silver crosses are to be considered parts of those which decorated the pallium offered by Matilda, documented with other gifts. ${ }^{55}$ In 1184 there was a second survey in the presence of Pope Lucius

one coin, he took away some from "that Idoll" (Moryson, An Itinerary, Vol. 1, p. 217). For the moral quality of coins being offered, with examples ranging from 1171 Dublin to 1619 Persia, see Travaini, "Saints, sinners and ...a cow", pp. 216-17.

53 For the Regola Bollata, see Merlo, "Francesco d'Assisi e il denaro". For the grave and the interpretation of coins as chronological signs: Travaini, "Saints and sinners", pp. 171-72 and Travaini, "Valori e disvalori", p. 31. According to Saccocci ("Un piccolo ripostiglio", p. 64), coins in saints' graves were offered as signs not of memory but of gratitude and a kind of tithe, as part of the coins offered to the altar. I still favour, however, the memory element, which has become more apparent in the course of my research.

54 For the grave in Modena: Missere Fontana and Travaini, Monete medievali e materialinella tomba di San Geminiano di Modena, pp. 35-57.

55 One similar cross was found in the hoard of Alife (Travaini, "La crocetta d'argento"). I have recently identified a mould used to produce such crosses in the Holy Land: see Rozenberg, Knights of the Holy Land, p. 24 O. 
III, who consecrated the new cathedral: fifty-three coins can be dated to this time. I believe that coins were used to indicate the time of these events. More evidence for such interpretation comes from the 1993 survey of the tomb of St Regolo in the Cathedral of Lucca. Previous surveys had taken place in the late 12th century, 1457, and 1658, and while the two later events were "signed" by placing a written record specifying the date and the name of the saint, the medieval one was recorded by leaving in the tomb 18 denarii in a cylindrical lead box, so that the coins were made into a close object by itself.5 ${ }^{5}$

Privileged graves were often identified by their prominent location and, inside, by explicit signs of identity such as inscribed lead plaques, especially widespread for kings or bishops in the 11th and 12th centuries. ${ }^{57}$ Philip Grierson, when trying to identify the tombs and obits of the Byzantine emperors, noted that in Antiquity the likelihood of a sarcophagus bearing a mark of identity "is in inverse proportion to the importance of its occupant; only a sovereign would take it for granted that his tomb would be generally recognized". ${ }^{8}$ For memory preserved inside a grave, compare the case of Emperor Lothar III (1125-1137) as recorded in the chronicle of Otto of Freising ("so that they could never be forgotten, the emperor's deeds were inscribed on sheets of lead and buried with him"). ${ }^{59}$

Occasionally, coins could also have served the purpose of personal memory, as in the case of the grave of Albert the Bear, margrave of Brandenburg (1124-1170), whose sarcophagus lies beside that of his wife Sophie (d. 116o) in the monastery of Ballenstedt. The coin found in his tomb was a bracteate which carried the image of the standing margrave and his wife, issued in c.1155-1160.60 Albert issued many different coin types from 1134, mainly

56 Macripò, "Un rinvenimento di monete", pp. 33-36.

57 See, for example, those found in the graves of Emperor Conrad II (1024-1039) and Empress Gisela (d. 1043) in Speyer Cathedral, or of Provost Humbert (d. 1086) in Maastricht: Waurick, Das Reich der Salier, pp. 289-9o and 339-41; lead Anglo-Saxon inscribed plates are listed in Okasha, "A third supplement to Hand-List of Anglo-Saxon Non-Runic Inscriptions".

58 Grierson, "The tombs and obits of the Byzantine emperors", p. 9 n. 35.

59 I quote from Morrison, History as a Visual Art in the Twelfth-Century Renaissance, p. 214. The original reads: ... honorifice sepelitur, [actusque eius, ut nulla possent aboleri oblivione, in plumbeis laminis descripti iuxta eum reconduntur]. According to the editor (but not noted by Morrison), the words in square brackets were added in the 13th century: cf. Otto of Freising, Ottonis Episcopi Frisingensis chronica, p. 340. The passage about the lead plaque may have been added at that time, but the plaque found in the tomb was presumably deposited at the time of the original burial. See Travaini, "Saints, sinners and ... a cow", pp. 212-13 and Travaini, "Saints and sinners", p. 169.

6o Röder, “Über den im grabe Albrechts”; and Bahrfeldt, Münzwesen der Mark Brandenburg, p. 79, pl. I, no. 20. 
bracteates, but only one showed him together with his wife and this was the very type that was chosen to accompany them in their grave. Whoever was responsible must have understood the relevance of the iconography to the context of this burial. The bracteate depicts a human relationship which continued in the afterlife.

Ordinary people were also occasionally buried with coins, but it is difficult to interpret their meaning as offerings, magic, or pars pro toto, standing in for other property. I would also suggest the possibility of personal memory, a token from the living to the dead. We will never know for sure. ${ }^{61}$

Some funeral rituals involving coins might have been considered improper for a Christian, but it is not easy to distinguish neatly between pagan and Christian behaviour, or between a good and a bad gesture, and it is indeed possible that the same gesture could be both pagan and Christian, or good and bad according to circumstances and intention. One coin in an ordinary grave as a rite of passage can be seen as the continuation of a pagan tradition, and we have written evidence of the Church's prohibiting such use, but the practice obviously did occasionally persist: St Augustine insisted that funeral offerings, meals, and celebrations should be abolished, yet they remained in use. ${ }^{62}$

Let us now investigate the idea of memory more closely. Placing coins in a saint's grave was most likely due to the need of chronological memory, the desire to create a certificate of time. Placing coins in the foundation of buildings was in part a propitiatory act, an offering to God, but also a sign of memory, varying according to time and context. ${ }^{63}$ In 14 th-century Italy foundation rituals started to involve purpose-made medals (Padua), but coins still remained

61 For the hypothesis of offers as pars pro toto, see Grinder-Hansen, "Charon's fee in ancient Greece?". For bibliography on coins in graves, see Travaini, "Saints and sinners", pp. 100-1. Hoards or bags of coins in graves ("dead man's treasure") may have been deposited voluntarily, but may have simply been left with a body untouched, e.g., in case of plagues: see ibid, pp. 177-79, corrected in Travaini, "Saints, sinners and ...a cow", pp. 213-15; Saccocci, "Un piccolo ripostiglio", pp. 63-64.

62 Boureau, "A royal funeral of 1498", p. 61. In 16th-century Lombardy documents inform us that a black hen was the fee to be paid to Saint Peter, replacing the obol to Charon: Travaini, "Valori e disvalori", p. 39. For more material and discussion of ritual uses of coins in various contexts, see Travaini, Santi, peccatori, un vitello e Giuda.

63 According to an anonymous 14th-century chronicler, many coins were deposited in the foundation of the Torre del Mangia in Siena in 1325 "for memory of the tower" (alquanta moneta per memoria di detta torre: Cronache senesi, pp. 129-30). This is so far the only medieval written evidence on such intention, but see below for one in 146o. For foundation offerings from antiquity to the Middle Ages, see Travaini, "Saints and sinners", p. 175; and Travaini, "Saints, sinners and ... a cow", pp. 218-21. (The "cow"-actually a calf-with a 
in use for this purpose for some time. ${ }^{64}$ I will not touch on this topic in detail, but wish to highlight the foundation ceremony planned by the Florentine architect Antonio Averlino, known as Filarete, for Francesco Sforza's new city of Sforzinda as written by him in the "trattato di architettura" of 1460, in the form of a dialogue between himself and the signore. The architect explains that the ceremony of the laying of the first stone will include the presence of notable people and religious authorities, musicians, the lord's sons, and the architect himself. They will lay a marble stone inscribed with the year and the names of the signore, the bishop, and the architect, on top of which will be a marble chest containing a bronze book listing all notable things of their time and of the men who achieved them, and also many medals of important men (molte effigie d'huomini degni); it will also contain stone vases full of millet, wheat, water, wine, milk, oil, and honey. When the signore asks the reason for all this, Filarete replies that human things have an end, so when the time comes, their things will be found and they too will be remembered, just as they remember earlier generations when looking at antiquities found by excavation or by cause of ruin. ${ }^{65}$

\section{Mistaken Identity}

People were used to their everyday coins and identified with them, but at the same time they could find some special interest in the occasional foreign or ancient coin they might come across. There is still a lot to investigate in medieval coin iconography and how it was perceived by the public, but as I started to extend my research to include iconography I had to reconsider many coins and

Milanese denaro of Frederick II in its mouth, was discovered in a mid-15th-century foundation context in a church at Caronno Pertusella, Varese: details and bibliography Ibid., pp. 220-21). Coins were also found hidden in a sealed niche under the floor of the small church of San Damiano in Assisi, rebuilt by Saint Francis in 1205. Saccocci, "Le monete", considers these coins as a personal "ex-voto" offering by the saint, but I believe they were intended as a form of foundation deposit according to an existing tradition; also, it has been observed that the hagiographic episodes of his restoration of the small churches of San Damiano and Santa Maria della Porziuncola have more of a symbolic value than a realistic one, and therefore the saint can hardly be imagined as the material builder (Travaini, "Valori e disvalori", p. 44; and Travaini, "Saints, sinners and ...a cow", p. 219). For a debate on the interpretation of medieval foundation offerings in Italy, see the bibliography in Travaini, "Saints, sinners and ...a cow", p. 220 n. 36 and a synthesis in Bernardelli, "In defossis locis", p. 383 .

64 For medals in building foundations, see Schraven, "Out of sight, yet still in place".

65 Filarete, Trattato di Architettura, pp. 102-6. 
take a closer look at how medieval people of various social statuses could have understood, or misunderstood, coin images in often-unexpected ways. I will give here one example.

The latest Byzantine gold coins recorded in Italian finds so far are three histamena of the same class, bearing on one side the bearded Basil II (976-1025) holding a cross, together with his son, Constantine viII. Each of these coins was found as a single specimen in one of three hoards: ${ }^{66} 1$ ) the Ordona hoard, from northern Apulia, deposited after c.1025, consisting of 147 taris of Salerno and one histamenon; ${ }^{67}$ 2) the Rome (Torre delle Milizie) hoard, deposited c.1185, containing billon denari of Lucca, Pavia, and Provins in Champagne as well as one histamenon; and 3) the Pisa (Logge dei Banchi) hoard, deposited c.1266, which consisted of 119 Sicilian Hohenstaufen taris, 16 augustales and one half-augustalis of Frederick II, 91 gold florins of Florence, one gold grosso of Lucca, and one histamenon.

Before working on coin iconography in detail, I thought that the single Byzantine coins were hoarded for their monetary value, but now I believe they were hoarded as devotional icons. We can identify them with the santalene d'oro from Italian coin lists dated $c .1280-1315$ and contained in Italian merchant and arithmetical books; they are not mentioned in later lists. The word "santalena" can only refer to St Helena, implying a female holding a cross, and possibly some connection with Constantine, on Byzantine coins. So I went back to the three hoards, thinking that each single histamenon of Basil II and Constantine viII was hoarded as an icon of St Helena and Constantine, long past the time when they could have been hoarded for their monetary value: the bearded Basil II was "read" by medieval Italians as Constantine the Great, and the beardless young Constantine VIII was perhaps "read" as St Helena. ${ }^{68}$

66 For the type, see Grierson, Catalogue, Vol. 3, Part 2, p. 621; for the three hoards, Travaini, "Les frontières de l'éternité?".

67 The taris in the Ordona hoard, attributed to both Salerno and Amalfi in Grierson and Travaini, $M E C$ 14, p. 419, must now be attributed to Salerno only: see Travaini, La monetazione nell'Italia normanna, p. $3^{*}$.

68 For details on this interpretation, see Travaini, "Les frontières"; in the 16th century any Byzantine coin bearing a cross would be perceived as a "medal of St Helena", and this was the case for the coins of the Lateran hoard found in 1586 , which gave origin to the numismatic papal bull of 1587 (text and comments Ibid., pp. 173-83). Byzantine coins-especially those with two figures, either of the type with two rulers or the one showing the Virgin crowning or blessing the emperor, interpreted as Constantine and Helena-are the most common among those found in collections, often pierced or reproduced in bronze as devotional medals: see Morrisson and Bendall, "Byzantine 'medals' "; also Travaini, "Coins, images, identity, and interpretations". 


\section{Conclusion: Coins as Proof of Identity}

We have seen the coins at the heart of the State, from the moment of their creation to the orders passed on to the mints. We have seen how mints could provide the means for the transmission of ideas and power. We have seen how people used and identified with their everyday coins, and how coins became means of transactions between man and God. But there is more to say.

Coins were many, and of many mints, with different details and sizes and metals, each unique in itself. This is why they were, extraordinarily, used as tokens of identity and security at the gates of the cities of Parma and Reggio Emilia and the fortresses in their territories. In 1409 Uguccione Contrari, commander of the army of the Marquis of Ferrara Niccolò III of Este, had recently taken the two cities and the surrounding area, but they were still under threat of further attack. He devised a system of signa whereby at each gate a particular coin had to be shown to the guards in order to enter. A total of 30 coins for 30 gates are listed with great detail: possibly there were two specimens for each gate (one for the gatekeeper and one for the person to be admitted), or else one specimen was in the hands of the person to be admitted and the keepers had with them a detailed description or a reproduction. ${ }^{69}$

Coins can thus interconnect the strings of many different fields of research, offering us endless surprises, from the very practical need of security to the less palpable traces of emotions.

\section{Bibliography}

\section{Primary sources}

Aquinas, Thomas. Tractatus de regimine principum (de rege et regno), in Opera Omnia, vol. 27, S.E. Fretté (ed.), Paris, 1875 .

Acta Imperii inedita seculi XIII, E. Winkelmann (ed.), 2 vols., Innsbruck, 188o-1885.

Cronache senesi, A. Lisini and F. Iacometti (eds), 2nd ed., vol. 15, part 6, Bologna, 1939. Filarete, Trattato di Architettura [di] Antonio Averlino detto il Filarete, A.M. Finoli and L. Grassi (eds.), introduction and notes by L. Grassi, Milan, 1972.

Huillard-Bréholles, J.-L.-A. (ed.), Historia diplomatica Friderici secundi Vol. 6, Part 2, Paris, 1861.

Isidore of Seville, Isidori Hispalensis Episcopi Etymologiarum sive Originum Libri XX, W. Lindsay (ed.), Oxford, 1911.

69 Travaini and Bazzini, "Signa Uguccionis". For identification in the Middle Ages, see Groebner, Der Schein der Person. 
Monumenta Germaniae Historica Vol. 10, Part 2: Diplomata regum et imperatorum Germaniae: Friderici I, diplomata, H. Appelt (ed.), Hanover, 1979.

Otto of Freising, Ottonis Episcopi Frisingensis chronica: sive historia de duabus civitatibus, A. Hofmeister (ed.), Hanover, 1912.

Procopius, History of the Wars, H.B. Dewing (ed.), 5 vols., London, 1914-1928.

Ptolemy of Lucca, On the Government of Rulers (De Regimine Principum), J.M. Blythe (trans.), Philadelphia, 1997.

Villani, G., Villani's Chronicle: Being Selections from the First Nine Books of the Croniche Fiorentine of Giovanni Villani, 2nd ed., P.H. Wicksteed (ed.), R.E. Selfe (trans.), London, 19o6. http://archive.org/stream/villanischronicl33022gut/pg33022.txt.

\section{Secondary Literature}

Alram, M., "Monnayage, prestige et identité de Rome à Persepolis et en Chine", Bulletin de la Société Française de Numismatique 65, no. 10 (2010), 276-84.

Alteri, G., "Le monete dal sarcofago di Catervio", Bollettino di Numismatica 26-27 (1996), 7-12, 19-168.

Arslan, E.A., "Il dono di re Carlo all'apostolo Pietro: un tremisse d'oro", Numismatica e Antichità Classiche. Quaderni Ticinesi 37 (2008), 377-406.

Arslan, E.A., "San Michele: un arcangelo per i longobardi", Numismatica e Antichità Classiche. Quaderni Ticinesi 30 (2001), 273-93.

Arslan, E.A., and Alteri, G. (eds), Le monete della tomba di san Pietro, Vatican City, forthcoming.

Arthur, P., "Le monete", in P. Arthur (ed.), Da Apigliano a Martano: Tre anni di archeologia medioevale (1997-1999), Lecce, 1999, 51-53.

Bahrfeldt, E., Münzwesen der Mark Brandenburg, Berlin, 1889 .

Bedos-Rezak, B.M., "Medieval identity: a sign and a concept", in Solway, Medieval Coins and Seals, 23-63 (published previously in American Historical Review 105 [2000], 1489-1533).

Bernardelli, A., "In defossis locis dispersae, vel muris intus locatae ... Considerazioni su un uso rinascimentale della medaglia, le origini: secoli XIV e XV", Rivista Italiana di Numismatica 111 (2010), 363-402.

Bompaire, M., "La monnaie de Pont-de-Sorgues dans la première moitié du XIVe siècle", Revue Numismatique, 6th ser., 25 (1983), 139-76.

Bompaire, M., "Tanquam monetam patrie propriam (Clermont, 1282). Une approche des identités monétaires médiévales? ", Revue Numismatique 169 (2012), 35-46.

Boureau, A., "A royal funeral of 1498", in M. Rubin (ed.), Medieval Christianity in Practice, Princeton, 2009, 59-63.

Bremond, C., Le Goff, J., and Schmitt, J.-C., L“"Exemplum” (Typologie des Sources du Moyen Âge Occidental, 40), Turnhout, 1982. 
Callegher, B., “Da imperatore a santo militare: 'San Costantino' su monete e sigilli tra XII e XIII secolo", Numismatica e Antichità Classiche. Quaderni Ticinesi 38 (2009), $285^{-3} 3$.

Coupland, S., "Carolingian single finds and the economy of the early ninth century", Numismatic Chronicle 170 (2010), 287-319.

Crusafont, M., Balaguer, A.M., and Grierson, P., Medieval European Coinage, with a Catalogue of the Coins in the Fitzwilliam Museum, Cambridge, Vol. 6: The Iberian Peninsula, Cambridge, 2013.

Day, W.R. Jr, "Antiquity, Rome and Florence: coinage and transmissions across time and space", in C. Bolgia, R. McKitterick, and J. Osborne (eds), Rome across Time and Space: Cultural Transmission and the Exchange of Ideas, c.500-1400, Cambridge, 2011, 237-62.

Elkins N.T., and Krmnicek, S.(eds), "Art in the Round": New Approaches to Ancient Coin Iconography (Tübinger Archäologische Forschungen, 16), Rahden, 2014.

Frugoni, A., "Il giubileo di Bonifacio VIII", Bullettino dell'Istituto Storico Italiano per il Medio Evo 62 (1950), 1-121.

Grandjean, C., "Identité civique et réalités monétaires en Grèce ancienne", Revue $\mathrm{Nu}$ mismatique 169 (2012), 11-21.

Grierson, P., Catalogue of the Byzantine Coins in the Dumbarton Oaks Collection and in the Whittemore Collection, Vol. 3, Parts 1-2: Leo III to Nicephorus III, 717-1081, Washington D.C., 1973.

Grierson, P., The Coins of Medieval Europe, London, 1991.

Grierson, P., “'Coniazioni per dispetto' nell'Italia medievale”, Numismatica e Antichità Classiche. Quaderni Ticinesi 8 (1979), 345-58 (reprinted in Grierson, Scritti, 303-58).

Grierson, P., "The fineness of the Venetian ducat and its imitations", in W.A. Oddy (ed.), Metallurgy in Numismatics (Royal Numismatic Society, special publications, 19), London, 1988, 95-104 (reprinted in Grierson, Scritti, 317-26).

Grierson, P., “The 'Gratia Dei Rex' coinage of Charles the Bald”, in M.T. Gibson and J.L. Nelson (eds.), Charles the Bald: Court and Kingdom, and ed., Aldershot, 1990, 52-64.

Grierson, P., The Origins of Money, London, 1977 (reprinted in Grierson, Scritti, 69-106).

Grierson, P. "The Roman law of counterfeiting”, in R.A.G. Carson and C.H. Sutherland (eds.), Essays in Roman Coinage Presented to Harold Mattingly, Oxford, 1956, 240-61 (reprinted in Grierson, Scritti, 107-28).

Grierson, P., Scritti storici e numismatici, E.A. Arslan and L. Travaini (eds.), Spoleto, 2001. Grierson, P., "The tombs and obits of the Byzantine emperors (337-1042)", Dumbarton Oaks Papers 16 (1962), 3-6o.

Grierson, P., and Blackburn, M., Medieval European Coinage, with a Catalogue of the Coins in the Fitzwilliam Museum, Cambridge, Vol. 1: The Early Middle Ages (5th-10th Centuries), Cambridge, 1986. 
Grierson, P., and Travaini, L., Medieval European Coinage, with a Catalogue of the Coins in the Fitzwilliam Museum, Cambridge, Vol. 14: Italy (III) (South Italy, Sicily, Sardinia), Cambridge, 1998.

Grinder-Hansen, K., "Charon's fee in ancient Greece? Some remarks on a well-known death rite", Acta Hyperborea 3 (1991), 207-18.

Groebner, V., Der Schein der Person. Steckbrief, Ausweis und Kontrolle im Mittelalter, Munich, 2017.

Gullbekk, S., "The church and money in Norway c.1050-1250: salvation and monetisation", in G.E.M. Gasper and S.H. Gullbekk (eds.), Money and the Church in Medieval Europe, 1000-1200: Practice, Morality and Thought, Farnham, 2015, 223-43.

Hendy, M.F., Studies in the Byzantine Monetary Economy c.30o-1450, Cambridge, 1985.

Howgego, C., Ancient History from Coins, London, 1995.

Ingham, J., The Nature of Money, Cambridge, 2004.

Kemmers, F., and Myrberg, N., "Rethinking numismatics: the archaeology of coins", Archaeological Dialogues 18 (2011), 87-108.

Macripò, A., "Un rinvenimento di monete nel sepolcro di san Regolo", Bollettino dell'Accademia Lucchese di Scienze Lettere e Arti 6, no. 1 (Gennaio-Marzo 1995), 33-36.

Malmer, B., The Anglo-Scandinavian Coinage c.995-1020, Stockholm, 1997.

Malmer, B., Den svenska mynthistorien. Vikingatiden ca 995-1030, Stockholm, 2010.

Martinori, E., Annali della Zecca di Roma, 1 (Urbano V, 1362-70, Giovanni XXIII, 141015), Rome, 1917.

Melville Jones, J.R., Testimonia Numaria: Greek and Latin Texts concerning Ancient Greek Coinage, 2 vols., London, 1993-2007.

Merlo, G.G., "Francesco d'Assisi e il denaro", in L. Travaini (ed.), Valori e disvalori simbolici delle monete. I 30 denari di Giuda, Rome, 2009, 145-52.

Metcalf, D.M., Coinage of the Crusades and the Latin East in the Ashmolean Museum Oxford, 2nd ed., London, 1995.

Missere Fontana, F., and Travaini, L., Monete medievali e materiali nella tomba di San Geminiano di Modena, Nonantola, 2005.

Morrison, K.F., History as a Visual Art in the Twelfth-Century Renaissance, Princeton, 1990.

Morrisson, C., and Bendall, S., "Byzantine 'medals': coins, amulets and piety", in D. Sullivan, E. Fischer, and S. Papaioannou (eds.), Byzantine Religious Culture: Studies in Honor of Alice-Mary Talbot, Leiden, 2012, 217-38.

Moryson, F., An Itinerary, Glasgow, 1907.

Müller, R.C., "Limperialismo monetario veneziano nel Quattrocento", Società e Storia 8 (1980), 277-97.

Muntoni, F., Le monete dei Papi e degli Stati pontifici, 4 vols, Rome, 1972.

Oberlaender-Târnoveanu, E., "Immo verius subucati Venetiarum communis proprio stigmate'. La question des émissions d'or de Francesco Ier Gattilusio, seigneur de Metelino (1355-1384)", Revue Numismatique 16o (2004), 223-40. 
Okasha, E., "A third supplement to Hand-List of Anglo-Saxon Non-Runic Inscriptions", Anglo-Saxon England 33(2004), 225-81.

Picard, O., "Iconographie et mémoire monétaires: l'exemple de Thasos", Obolos 9 (2010), 45-57.

Pigozzo, F., “I denari dei pellegrini. Oblazioni votive e istituzioni ecclesiastiche nell'Italia centrale alla fine del XIV secolo", in Religione e istituzioni religiose nell'economia europea (1000-180o), Atti della XLIII Settimana di Studi dell'Istituto internazionale di storia economica “F. Datini", Prato, 8-12 Maggio 2011, Florence, 2012, 743-53.

Pliego Vásquez, R., La moneda visigoda, Seville, 2009.

Röder, V. von, "Über den imgrabe Albrechts des Bären zu Ballenstedt aufgefundenen brakteaten”, Blätter für Münzfreunde 37 (1901), cols. 2747-49.

Rozenberg, S.(ed.), Knights of the Holy Land: The Crusader Kingdom of Jerusalem, Jerusalem, 1999.

Saccocci, A., "Le monete", in L. Ermini Pani, M.G. Fichera, and M.L. Mancinelli (eds.), Indagini archeologiche nella chiesa di San Damiano in Assisi, Assisi, 2005, 119-30.

Saccocci, A., "Un piccolo ripostiglio di grossi, quattrini e denari della seconda metà del XIV secolo dall'area della pieve di S. Giusto a Padule (Capannoli)", in G. Ciampoltrini (ed.), Peccioli e la Valdera dal Medioevo all'Ottocento. Itinerari archeologici fra Pisa e Volterra, Pisa, 2010, 63-77.

Sapori, A., "I primiviaggi di Levante e di Ponente delle galee fiorentine", Archivio storico Italiano 114 (1967), 69-91.

Sarah, G., "Charlemagne, Charles the Bald and the Karolus monogram coinage: a multidisciplinary study", Numismatic Chronicle 170 (2010), 227-86.

Schraven, M., "Out of sight, yet still in place: on the use of Italian Renaissance portrait medals as building deposits", Res: Anthropology and Aesthetics 55-56 (2009), 182-93.

Seaford, R., Money and the Early Greek Mind: Homer, Philosophy, Tragedy, Cambridge, 2004.

Serafini, C., "Le monete", in B.M. Apollonj Ghetti, A. Ferrua, E. Josi, and Engelbert Kirshbaüm (eds.), Esplorazioni sotto la Confessione della Basilica di San Pietro in Vaticano, Vatican City, 1951, 225-44, pl. 89-103.

Skaare, K., "Universitets Myntkabinett" [Annual Report], Nordisk Numismatisk Ársskrift 1973-1974, 154-55.

Solway, S. (ed.), Medieval Coins and Seals: Constructing Identity, Signifying Power, Turnhout, 2015 .

Spufford, P., Money and Its Use in Medieval Europe, Cambridge, 1988.

Stahl, A.M., Zecca: The Mint of Venice in the Middle Ages, Baltimore, 2000.

Suárez Otero, J., “Arqueologia y peregrinación: la moneda en la peregrinación maritima a Santiago", in Actas del II Congeso Internacional de Estudios Jacobeos (II), Santiago, $1998,195^{-218 .}$ 
Thompson, S., Motif-Index of Folk Literature: A Classification of Narrative Elements in Folktales, Ballads, Myths, Fables, Mediaeval Romances, Exempla, Fabliaux, Jest-Books and Local Legends, revised and enlarged ed., 6 vols., Bloomington, 1955-1958.

Travaini, L., I capelli di Carlo il Calvo: indagine sul ritratto monetale nell'Europa Medievale, Rome, 2013 .

Travaini, L., "Coins, images, identity, and interpretations: two research cases - a seventh-century Merovingian tremissis and a fifteenth-century ducat of Milan", in Solway, Medieval Coins and Seals, 65-80.

Travaini, L., "La crocetta d'argento", in E.A. Arslan et al., "Il ripostiglio di Alife", Rivista Italiana di Numismatica 116 (2015), 163-219, at 176-77.

Travaini, L., "Les frontières de l'éternité? le cas d'un nom de monnaie: santalene", Revue Numismatique 164 (2008), 169-83.

Travaini, L., "Imitations and adaptations of Arabic coins in southern Italy, Sicily and the Holy Land", in C. von Heijne, L. Treadwell, and M. Jankowiak (eds.), Early Medieval Imitational Coinages (Nordic Numismatic Journal, s. 2), forthcoming.

Travaini, L., Il lato buono delle monete: devozione, miracoli e insolite reliquie, Bologna, 2013.

Travaini, L., "La moneta in viaggio", in G. Piccinni and L. Travaini, Il Libro del pellegrino (Siena, 1382-1446). Affari, uomini, monete nell'Ospedale di Santa Maria della Scala (Nuovo Medioevo, 71), Naples, 2003, 83-158.

Travaini, L., La monetazione nell'Italia normanna, Seconda edizione con aggiornamento e ristampa anastatica, Zürich and London, 2016 (1st edition, Rome, 1995).

Travaini, L., "Le monete a Fontana di Trevi: storia di un rito", Rivista Italiana di Numismatica 101 (2000), 251-59.

Travaini, L., "Per Philip Grierson. I romanini d'oro nella seconda metà del Duecento", Rivista Italiana di Numismatica 108 (2007), 295-304.

Travaini, L., "Sacra moneta: divinity, purity, miracles and powers", in N.M. Burström and G. Tarnow Ingvardson (eds.), Divina Moneta: Coins in Religion and Ritual, Abingdon, 2018.

Travaini, L., "Saints and sinners: coins in medieval Italian graves", Numismatic Chronicle 164 (2004), 159-81.

Travaini, L., "Saints, sinners and ... a cow: interpreting coins in ritual contexts", in G.E.M. Gasper and S.H. Gullbekk (eds.), Money and the Church in Medieval Europe, 1000-1200: Practice, Morality and Thought, Farnham, 2015, 209-21.

Travaini, L., Santi, peccatori, un vitello e Giuda. Gli usi rituali delle monete nel medioevo, Lucca, forthcoming.

Travaini, L., "Valori e disvalori simbolici delle monete: temi, problemi, interpretazioni", in L. Travaini (ed.), Valori e disvalori simbolici delle monete nel medioevo. I Trenta denari di Giuda, Rome, 2009, 13-61. 
Travaini, L., and Bazzini, M., “'Signa Uguccionis': monete come prova di identità tra Parma e Reggio Emilia nel 1409", Revue Numismatique 172 (2015), 391-449.

Travaini, L., and Broggini, M., Il Tesoro di Montella (Avellino): ducati e fiorini d'oro italiani e stranieri occultati nella metà del Trecento, Rome, 2016.

Tripodi C., "Viaggi di ambasciatori tra Firenze e Il Cairo nel xv secolo", Mélanges de l'École Française de Rome: Moyen Âge 122 (2010), 411-40.

Waurick, G. (ed.), Das Reich der Salier 1024-1125: Katalog zur Ausstellung des Landes Rheinland-Pfalz. Ausstellung im Historischen Museum der Pfalz, Speyer, vom 23. März bis 21. Juni 1992, Sigmaringen, 1992.

Wittreck, F., 2002, Geld als Instrument der Gerechtigkeit. Die Geldrechtslehre des Hl. Thomas von Aquin in ihrem interkulturellen Kontext (Rechts- und Staatswissenschaftliche Veröffentlichungen der Görres-Gesellschaft N.F., 100), Paderborn, 2002. 